\title{
Route-Based Tourism Product Development as a Tool for Social Innovation: History Valley in the Cserehát Region
}

\author{
KATALIN NAGY \\ ASSISTANT LECTURER \\ UNIVERSITY OF MISKOLC \\ e-mail: marnk@uni-miskolc.hu
}

\author{
ISTVÁN PISKÓTI, CSc \\ PROFESSOR \\ UNIVERSITY OF MISKOLC \\ e-mail: piskoti@uni-miskolc.hu
}

\section{SUMMARY}

Route-based tourism product development is known worldwide, and can be particularly advantageous for less developed areas, which are less familiar in the tourism market. By mixing the phenomena of tourism, the economy, innovation and social difficulties, certain types of tourism routes can be tools for social innovations, if they are combined with spatial development, support of local communities and integration of local products. The first part of this study gives a literature review regarding route-based tourism products, alongside the explanation of conceptual differences. In the second part, we introduce the so-called "History Valley" in the Cserehát region, with a multi-view analysis.

Keywords: route tourism, thematic routes, rural development, social innovation

Journal of Economic Literature (JEL) codes: M31, O22, O31, Z32

DOI: http://dx.doi.org/10.18096/TMP.2016.02.07

\section{INTRODUCTION, RESEARCH QUESTIONS}

Tourism is the most important service sector of the global economy. The economy of services, however, becomes the economy of experiences. Consumers do not buy simple products, rather complex experiences, and are willing to pay higher prices for products with value added. The general characteristics of the experience economy are essential in the case of tourism, as "tourism is the experience itself". Tourists are looking for local, authentic and meaningful experiences, which are intrinsic values of the visited places. One of the main challenges is that the demands are moving towards intangible culture and heritage. Thus, it is very important to find a balance between "new" and "different", or "typical", "specific" and "authentic". According to Boswijk et al. (2005), meaningful experiences are determinant, where innovation has an outstanding role, and have the following features: concentration and focus, all five senses are engaged, emotional touch, uniqueness, contact with reality, activity, playfulness, balance between a challenge and one's own capacities and a clear goal. Considering intangible heritage, the main goal should be to build (back) the identity of local communities and continuity (Pedersen 2004, cited in Schlüter 2012). Being proud of the local culture and identity is important element of a destination's value, and it is an essential condition of long-term survival. As opposed to tangible heritage and monuments, intangible heritage goes through constant and dynamic change due to its close relationship with a community's lifestyle. It has to become a living part of the community to fulfil its social, political, economic and cultural roles (Aikawa 2007, in Schlüter 2012). Innovations become more and more important to a tourism destination's competitive ability (Piskóti 2014). Therefore, culture, innovation and spatial development go hand in hand in creating tourism experience, and routebased product development is one of the best examples.

We have focused on a peripheral Northern Hungarian micro-region, the Cserehát, where a good concept, the History Valley thematic route, was created a few years ago. However, in spite of several developments and events, the route - as a tourism product - is not currently functioning well. We investigate the reasons, the present situation of the route and its attractions, and the possible tools - mainly of destination management - to make the route function again.

Our research was carried out within the framework of the T-model project, concentrating on the social entrepreneurship and tourism opportunities of deprived 
regions. This special issue includes papers presenting research carried out on similar issues: sustainable enterprise models (Illés 2016); sustainable accounting (Demény \& Musinszky 2016); establishing and operating social enterprises (Várkonyi 2016); the place of public works in the employment model of the Cserehát region (G. Fekete 2016); and the SLEM model as an assessment method for local goods' competitiveness (Bartha \& Molnár 2016).

\section{ROUTE-BASED TOURISM PRODUCTS - LITERATURE REVIEW}

A tourism product is the central element in the offer side of the tourism system. From the tourist perspective, the product is a set of services; its aim is the complete satisfaction of customer needs. The tourism product is the result of a complex process, with two main characteristics: (1) every phase results in value added, (2) the consumer (the tourist) is an integral part of the process. The demand for authenticity is a determining factor of cultural tourism, which differentiates it from the commercialised values. Establishing local brands is a recent possibility for local communities, with several examples in Hungary (e.g. national park products). According to Nuryanti (1996), heritage is part of the society's cultural traditions and a community's identity. It is a value from the past which is worth preserving for generations to come (Hall \& McArthur 1998). Referring to Swarbrooke's definition (1994), heritage tourism is based on heritage where it is both the central element of the product and the main motivation for tourists. Nowadays there is a significant oversupply in heritage attractions, and heritage tourism has become a strongly competitive and marketoriented product; thus, continuous development and product differentiation became essential for survival. Poon (1989, in Light \& Prentice 1994) called this product "new tourism". It has also become evident that heritage tourism product development is different from the traditional and general processes, and that there are different problems and variables that require different development models in various heritage categories - this is the case with route-based products, too.

Thematic routes are connecting natural or artificially made attractions, centred around a certain theme, and these attractions can be accessed by some means of transport. Regarding sustainability, thematic routes serve as education and entertainment at the same time (Puczkó \& Rátz 2000). The routes can be product or theme-based (Rogerson 2004, 2007, in Lourens 2007a). The primary objective of product-based routes is strengthening the core product's marketing and sales. Still, theme-based routes should not only focus on the destination's image; the theme has to appear in each service along the route (e.g. accommodations, restaurants, souvenirs). Thematic (or tourism) routes combine several activities and attractions within a theme, thus encouraging enterprises to produce further, complementary products (see Meyer 2004). Thus, route-based tourism is the market-driven approach of the destinations' development (Lourens 2007a). The main conception of route formation is that connecting activities and attractions in less developed areas can generate cooperation and partnership between communities and neighbouring areas, thus contributing to economic growth through tourism (Briedenhann \& Wickens 2004). Partnership in successful thematic route realisation means competitive advantages through local clusters (Telfer 2001, in Rogerson \& Rogerson 2011). In rural areas, success also depends on finding the USP (unique selling proposition) niches, together with the connecting products.

Cultural routes mean a new type of heritage preservation and utilisation. They mean both geographical travel through different areas and localities, and mental travel, with values, emotions, feelings and experiences, which will form the final product (Majdoub 2010). Cultural routes mean both a tourism product and a special methodology (Puczkó \& Rátz 2003, in Majdoub 2010). They are especially innovative within cultural heritage preservation (Martorell 2003). According to the Cultural Routes Charter of ICOMOS (International Council on Monuments and Sights, 2008), a cultural route is: any route of communication, be it land, water, or some other type, which is physically delimited and is also characterized by having its own specific dynamic and historic functionality to serve a specific and welldetermined purpose. It must fulfil the following conditions: (1) it must arise from and reflect interactive movements of people as well as multi-dimensional, continuous, and reciprocal exchanges of goods, ideas, knowledge and values between peoples, countries, regions or continents over significant periods. (2) It must have thereby promoted a cross-fertilization of the affected cultures in space and time, as reflected both in their tangible and intangible heritage; (3) it must have integrated into a dynamic system the historic relations and cultural properties associated with its existence.

Cultural routes are not literally created or planned, rather discovered - that is, they have historical significance, and have existed as roads in their physical reality. On the contrary, tourism routes are planned according to customers' interests, geographical structure, accessibility, attractions or any other respect, without any scientific basis (Martorell 2003).

Regarding the case study discussed below, we have to mention the centre-periphery model of Wallerstein (1983) as well. The basis of the model is the hierarchy where developing areas can become growth poles, or centres, with outstanding innovation abilities. Parallel to their continuous growth, other areas become more and more peripheral.

There is strong asymmetric dependence between the two elements, with the following characteristics: (1) the growth pole exploits the periphery's raw material and 
labour force, (2) its products' market is also the periphery, (3) central areas can be described with continuous growth, (4) peripheries remain distant, the development is slow. Central areas intervene (sic) the peripheries' life, their economic and social processes; they disarrange their development tendencies in favour of their own position. (in Graselli 2011.

This dependence is dynamic and shows a close relationship with spatiality (Kincses \& Rédei 2010). The centre-periphery model has become one of the main categories of regional science. Regarding research in Hungary, Budapest and its surroundings are considered central areas, the frontier areas of southern Transdanubia, northern Borsod and eastern Hungary represent the periphery, while the central Tisza area is mentioned as the internal periphery (Lőcsei \& Szálkai 2008).

\section{SPECIAL MODELS FOR ROUTE- BASED TOURISM DEVELOPMENT}

Cultural route conception needs a special methodology, a system of coordinated and integrated management in establishment and operation. According to the Cultural Routes Charter by ICOMOS, this methodology means the following elements:

1. research - multidisciplinary teams, common criteria system, co-ordination;

2. financing - priorities, cooperation, involvement of private and public sectors;

3. preservation, assessment, conservation - based on a heritage inventory; examination of authenticity and integrity;

4. sustainable utilisation, tourism - as a means of spatial development, too;
5. management - integrated methods, holistic approach;

6. community participation - involvement of local inhabitants.

Route-based developments have important role in job creation, community and economic development. Regarding planning - from the many different models and methods - we have chosen the allocationconcentration strategy as best fitting to the examined area. Allocation strategy means to disperse the visitors steadily in a certain area; thus, visitors can appear not only in the main centres, i.e. "gates". The three main targets are reduction of pressure on the central area/settlement; sharing the income from tourism; and the increase of a destination's general attractiveness by introducing new areas and characteristics. On the contrary, the theory of concentration introduces the phenomena of gateways, staging areas and clustering of attractions (Meyer 2004). Although it seems to be the reverse of allocation strategy, it is important to point out their relationship (Figure 1). The gateways refer to certain geographical entry points to a region (e.g. airports or highways). Staging areas normally mean the surroundings of gateways or bigger cities nearby, where tourists can find every facility for their stay (e.g. accommodation, shops and information offices). Clustering has the following advantages: better planning of integrated development, more efficient provision of transportation access and other infrastructure, convenience to tourists of facilities and services being in proximity, capability of concentrated development, a variety of and more specialised facilities and services, and containment of any negative environmental and sociocultural impacts. Thus, concentration strategy means controlled and integrated planning and development.

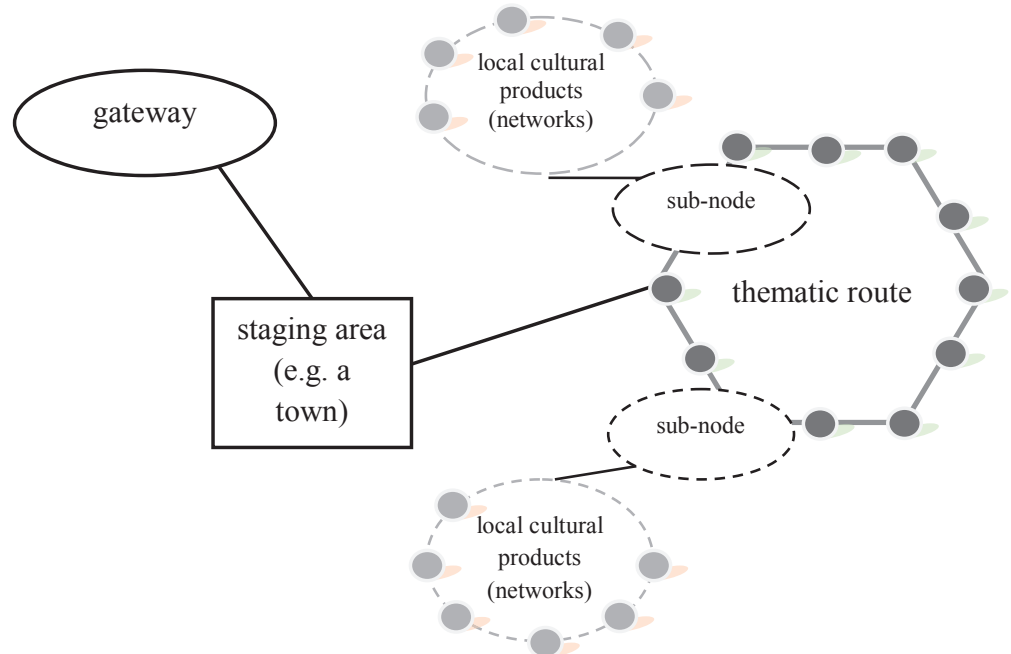

Source: after Meyer (2004) own compilation

Figure 1. Combination of allocation and concentration strategies for thematic routes 
The key elements of successful route development are (Meyer 2004):

1. cooperation networks, regional thinking and leadership;

2. product development, infrastructure and access;

3. community participation, micro-enterprise development and innovation;

4. information and promotion;

5. explicit "pro-poor" focus.

\section{RESEARCH SETTING - HISTORY VALLEY IN CSEREHÁT}

The Cserehát micro-region is a gentle hill-country in Northern Hungary, bordered by two rivers (Bódva and Hernád), and by Slovakia in the north. It is a natural "bridge" between two mountain ranges, the Bükk and the Zemplén (Figure 2). It is a typical traditional area with small villages. After the Treaty of Trianon (1920), it lost its natural economic relations with the northern areas (which were attached to Slovakia). From the 1960s, the area has been slowly declining, with high rates of migration and a growing gipsy population in the settlements. In spite of its peripheral economic situation, this calm area is very rich in natural and cultural potential.

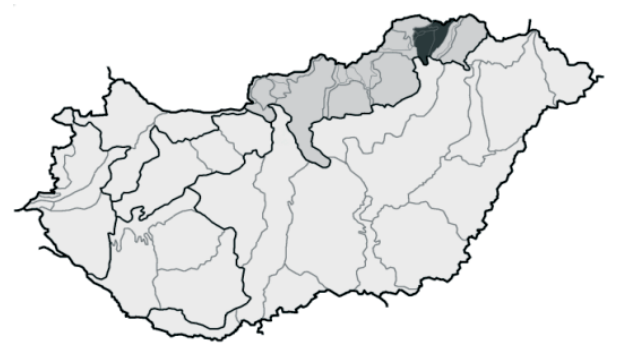

Source: http://www.wikiwand.com/hu/Cserehát

Figure 2. Geographic position of the Cserehát microregion within Hungary

The Cserehát Settlement Association has elaborated a project called "History Valley", based on previous tourism development experiences. The project defines the natural and historical heritage of the Bódva River and its surroundings as a complex tourism attraction; and offers the experience of "travelling in time" in a core area of 29 settlements. The intended effect contains representative old buildings, exhibitions with interactive elements, programs offering active participation, festivals, traditional costumes, gastronomic specialities and locally made souvenirs. According to the conception, the History Valley concept could be expanded to the whole Aggtelek-Edelény destination, as the route goes through a further 18 settlements, and even into the neighbouring Slovakian areas. Within the project, seven historic buildings were renovated or rebuilt, with modern tourism services; 15 historical or cultural exhibitions were created; three entry and information points were built; and five historic trails (3-8 $\mathrm{km}$ each) were marked. Certain marketing activities (signboards, brochures and website) have complemented these, and there was a training course for future staff members, too. The managers counted 20,000 visitors per year at the seven new staging points, which could assure the project's sustainability. The project - as an idea - has drawn up an integrated development vision, planned the clustering of existing attractions, new attractions and services, and future enlargement possibilities.

\section{Methodology}

During the examination, first we carried out a secondary research by reviewing the previous attraction inventory of the Northern Hungarian tourism region. We narrowed it to the sample area, i.e. the Cserehát microregion, improved with the new establishments, and also added other services to the investigation. Then, we carried out a questionnaire survey among tourists at outstanding attractions of the sample area.

\section{The Tourism Offer of the Cserehát Micro- region}

The first attraction inventory was collected in 2006, as part of the development strategy of the Northern Hungarian tourism region. Regarding the Cserehát microregion (98 settlements), the number of attractions identified was 296. As part of the T-Model project in 2015, we updated the inventory, finding a total of 462 attractions. The sample region was supplemented with some further places, as the route goes through the UNESCO World Heritage Site of Aggtelek, as an alternative route to the Cserehát, with outstanding attractions (Figure 3). Such growth in the number of attractions undoubtedly means several recent developments - nevertheless, there was not enough service development, especially in the field of accommodation, restaurants, events and organisations.

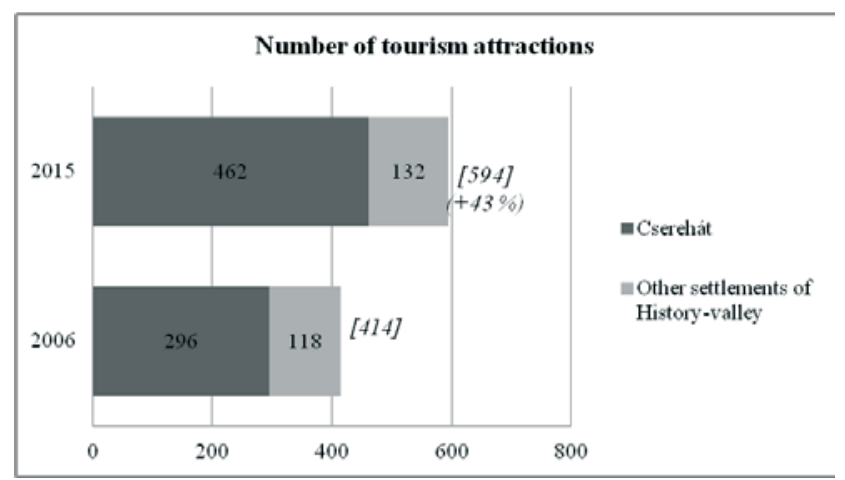

Source: own compilation on the basis of own database

Figure 3. Tourism inventory of Cserehát 
We can examine the attractions according to their attractive force, too, which means from how far they are able to attract visitors. For the present, we have categorised the elements of History Valley as microregional attractions, as the concept builds on mainly local, less known resources; however, this significantly limits the possible target groups, too. Altogether, regarding the data from 2015 , almost $50 \%$ of the total attractions are of local importance, while $28 \%$ are microregional, $9.5 \%$ regional, $8.5 \%$ national, and only $4 \%$ are of international importance (because of the world heritage site).

We determined 42 attraction types in the inventory, and categorised them into six bigger groups (Figure 4). The categorisation is mainly resource-based, which determines what type of tourism product can be built upon them. The graph shows that we can build upon cultural and natural resources. Gastronomy also appears as a good potential attraction.

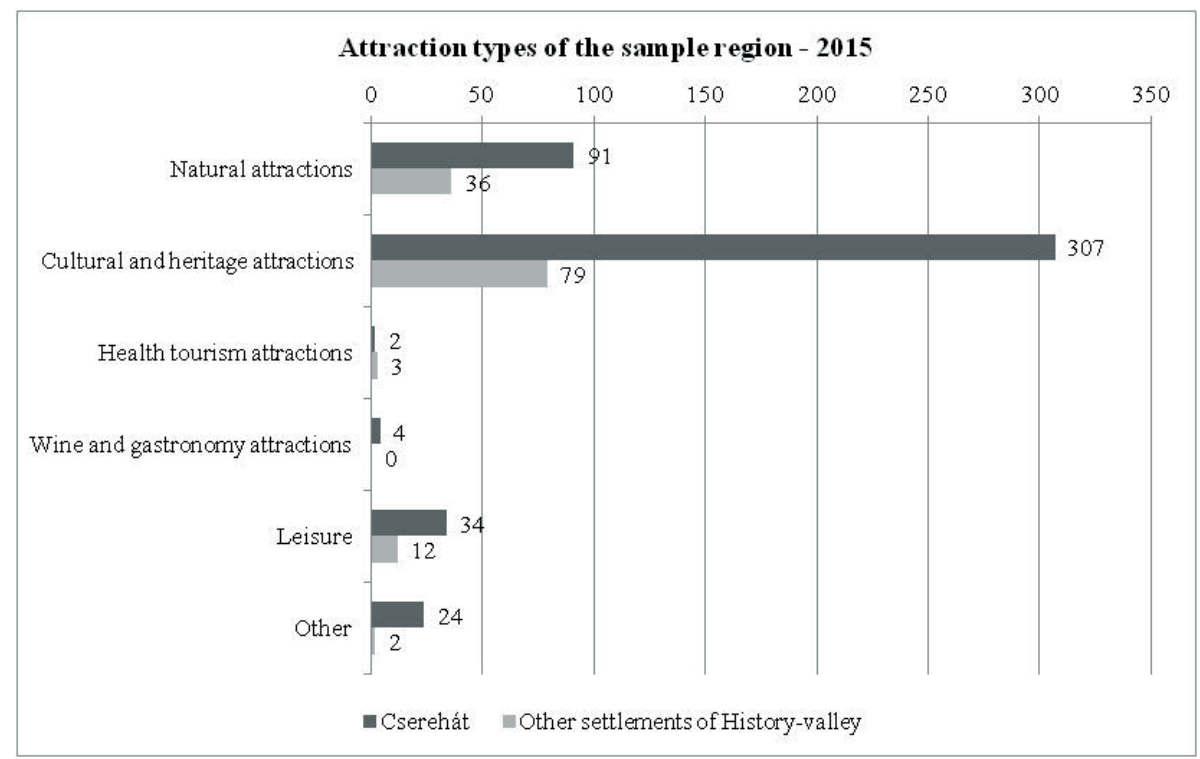

Source: own compilation on the basis of own database

Figure 4. Main attraction types in the sample region (Cserehát)

The inventory, however, is a little deceptive. When we look behind the numbers, we can find two interesting anomalies:

1. Within the group of cultural and heritage attraction, the most numerous type is historical buildings. Out of the total 133 buildings, $84(63.16 \%)$ are churches. Not undervaluing their importance in cultural and religious tourism, we can ask the following question: do these really have attractive force? Are they accessible for tourists? Unfortunately, in most cases, we have to answer "no"; the main reasons are the limited opening hours and the lack of professional interpretation and available information.

2. Thematic routes are also within the group of cultural and heritage attractions. The identified 51 elements in fact belong to five routes: History Valley, Medieval Churches, Panorama Route, Forts and Castles and the Gothic route. Thus, the 51 elements mean places of interest only. Though we do not have the opportunity to analyse this within this study, it is clear that route-based development - as a marketing tool - has some tradition in the area.

\section{MAIN FINDINGS, RESULTS}

\section{Other Services in the Sample Region}

Arising from the characteristics of the tourism product, it is not enough to examine only the (real or potential) attractions, but also other services. Though we cannot analyse all types of services within the scope of this study, we highlight three categories.

The offer of accommodations determines whether a destination is able to keep tourists there or whether they only travel through or make one-day excursions. Regarding the standpoints of the 3S strategy of the experience economy (stop, spend and stay longer) and spatial development, it is essential to have a satisfactory range of accommodation in number of beds/rooms/establishments, price and quality. We cannot declare this about our sample region (Figure 5): 


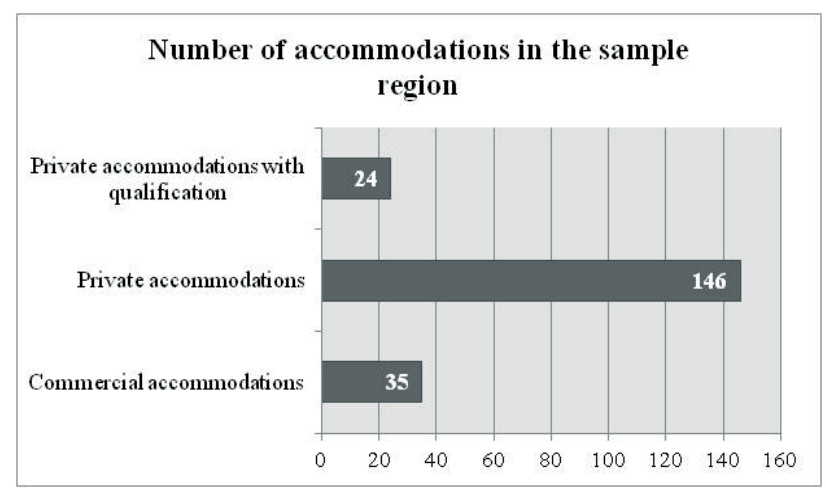

Source: own compilation on the basis of own database

\section{Figure 5. Types and number of establishments in the Cserehát}

In the sample region, private accommodations are significant, making up $80.66 \%$ of all establishments. There are only three hotels each in two districts of the region; the others are all tourist and youth hostels. It is even more interesting that only $16.44 \%$ of all the private accommodations have a quality trademark (the qualification system is ordained in Governmental Regulation 239/2009. (X.20.)). This depressing rate also determines the "visibility" of the whole region.

The situation is very similar in case of hospitality establishments (or, more typically, "places for eating"). It is difficult to find a suitable restaurant in the micro-region - there are mainly snack bars, pizzerias, and confectioneries in some towns. This fact hinders longer stays - particularly, when most of the accommodations (private ones) do not offer meals. Regarding all places for eating in the sample area, there are only 15 establishments (44.12\%) which belong to the "restaurant" category (most of them within a hotel).

The third highlighted area is the tourism institution system and human resources. There was a Tourinform (tourist information) office in Edelény several years ago; first maintained by the Cserehát Settlement Association, then the local municipality, but it was closed in 2007 or 2008. The area was unable to participate in the destination management development program (which started in 2009); because they could not produce data for even the minimum indicators needed (number of guests, guest nights, tourism tax, etc.). This is despite the fact that this area, neighbouring the Aggtelek world heritage site, is one of the six major tourism districts of the Northern Hungarian tourism region, as defined by the regional tourism strategy. In spite of the existence of some (older or newer) civil organisations, their cooperation does not function; the entrepreneurs and other stakeholders could not form a network. The previous projects (e.g. CSER-KÉK rural tourism network) slowly sink into oblivion, and we can say that History Valley does not function properly, either. This loop of the chain is completely missing.
Practically we can declare that, although the area has great potential for the development of certain types of tourism, there are no services that can turn the attractions into tourism products. The quiet resignation of the local people and the lack of the necessary way of thinking, entrepreneurship and community force all "crown" this situation.

\section{The Results of the Visitor Survey}

We carried out a visitor survey in the sample region, in two rounds. First, we asked a reference group, who were participants of the "Periphery" Summer University in Irota. The questionnaire focused on awareness of the area as a whole and of History Valley as a thematic route, and the expectations regarding route tourism. The survey was not representative. In the second round, we asked tourists at main attractions of the sample area, at the castle of Edelény and around other sights.

Demography of all participants: $61 \%$ women, 39\% men. Age: 2\% between 16-19 years, 39\% 20-29 years, 24\% 30-39 years, $13 \%$ 40-49 years, 15\% 50-59 years old, and $7 \%$ are 60 or older. Highest educational level: $40 \%$ have completed secondary school, $30 \%$ have college degrees (3-year degree or bachelor's degree), 19\% university qualifications (5-year degree or master's degree, while $9 \%$ have a $\mathrm{PhD}$ degree. Place of residence: $27 \%$ of the visitors live in Miskolc (seat of BorsodAbaúj-Zemplén County, where the Cserehát micro-region can be found), and $41 \%$ live in other settlements of the county (Figure 6); this reflects the mainly local importance of the attractions, as we have stated before. During the survey, we met no foreign visitors.

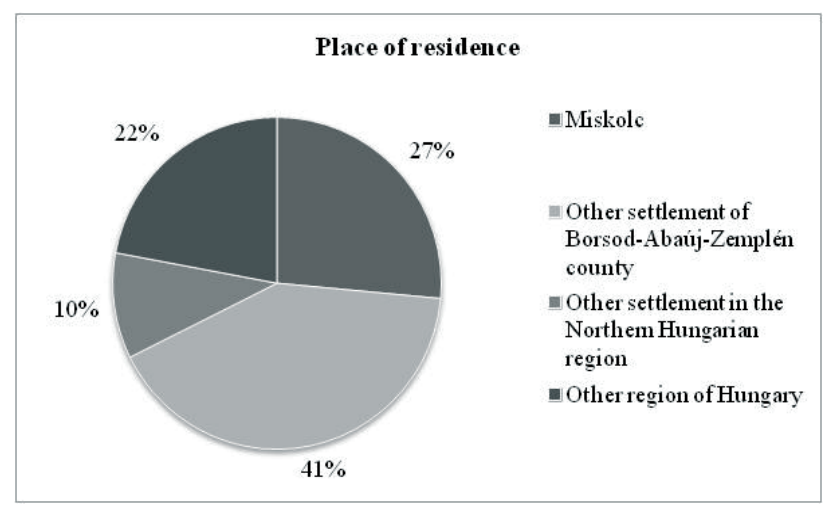

Source: own compilation Figure 6. Permanent place of residence of the visitors
participating in the survey

Groups: $36 \%$ of the visitors arrived with their partner or spouse, $25 \%$ with friends and $23 \%$ with family (children) to the sample area. Length of stay: $58 \%$ arrived for a one-day excursion, and only $24 \%$ spent $1-3$ days in the region; of this group, only half of them had their accommodation there, a quarter of them at friends or relatives. Regarding the motivations, $44 \%$ of the visitors 
choose excursion, 23\% scientific activities (reference group in the Summer University) and $15 \%$ visiting cultural attractions.

In the second part of the questionnaire, we asked the tourists' opinion about the region. First, they had to express agreement or rejection of certain statements, on a scale of 1-5 (Figure 7). The lower third of the graph relatively well shows the lack of different services in the region, as we described before when analysing the attractions and offers. Most of the respondents have the opinion that the area is affordable, and they find the services and products have reasonable prices; while many of them think that it is a cheap destination. There is quite a big difference in this question between the reference group members and the daily tourists; the reason is that the academic participants of the summer university have a much higher average income than the average tourist. They are also more critical about the quality, too (Figure 8).

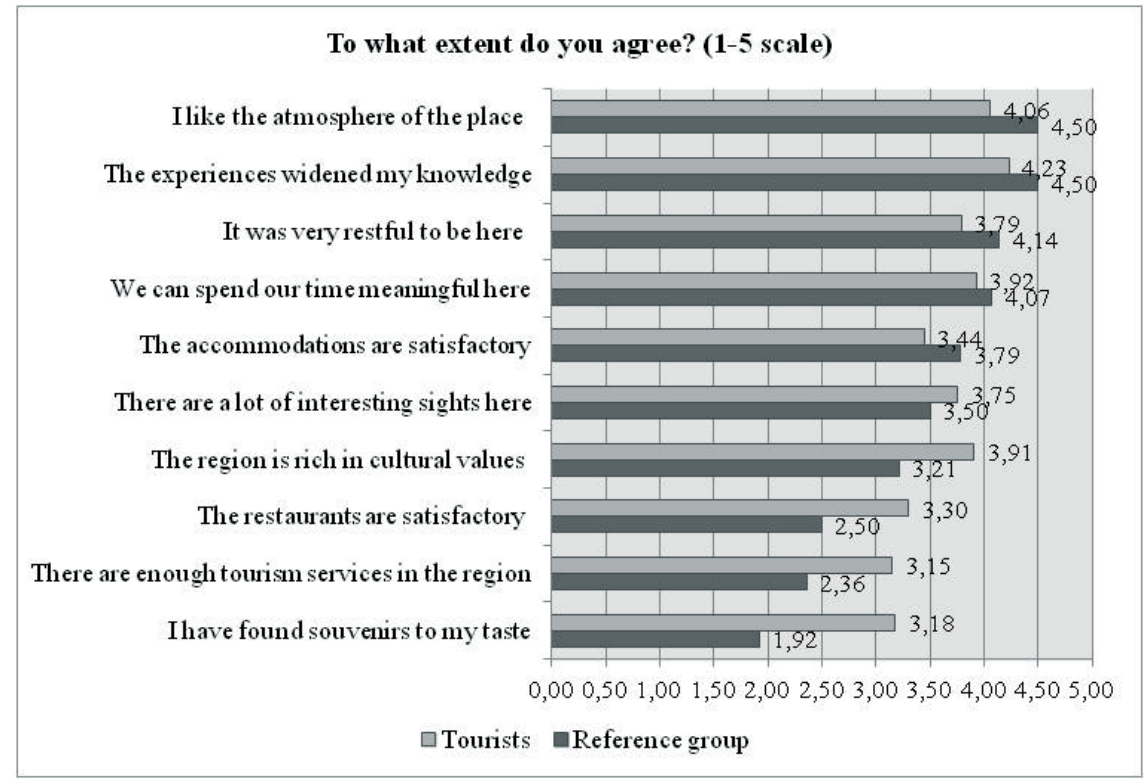

Source: own compilation

Figure 7. Opinions about the region (1-not at all, 5 - completely)

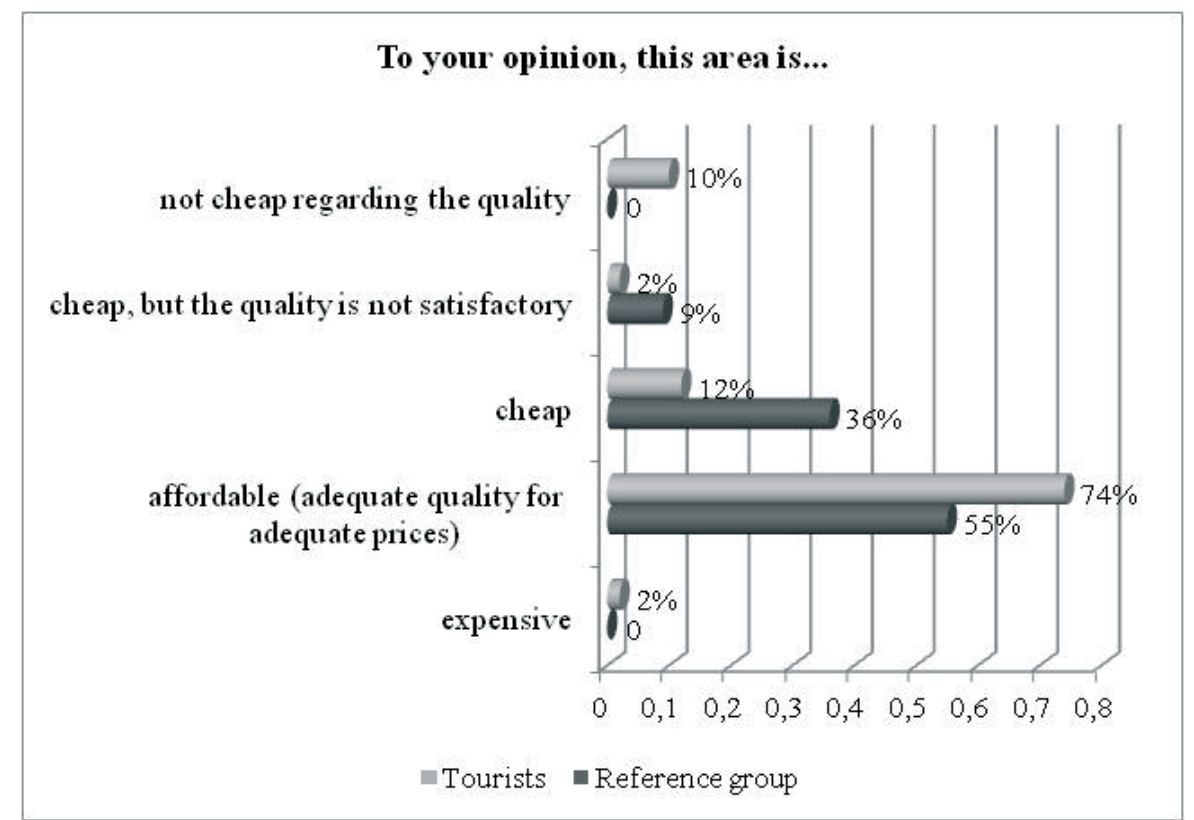

Source: own compilation

Figure 8. Opinions about the region 
The third part of the questionnaire is related to the thematic routes in general, and the History Valley route. Of the reference group, $61.5 \%$ of the reference group knew about the thematic routes but $77 \%$ of them had not visited any before, and $64 \%$ had not heard about the History Valley route - though they had been here for the third time on average. The same questions show very different results among day trip tourists: $77 \%$ had not heard about thematic roads, and 94\% had not visited any of them before; $81 \%$ had not heard about the History Valley route. In the following section, we asked the importance of certain aspects of thematic routes, on a 1-5 scale; these aspects will appear in our model that we suggest for the revitalisation of the History Valley program (Figure 9). The most surprising is that the criterion of authenticity was given the lowest value; although we consider it as one of the most important aspects for cultural and heritage-based routes, which determines the tools and methods of interpretation, too. Similarly, the range of services received quite a low value, too.

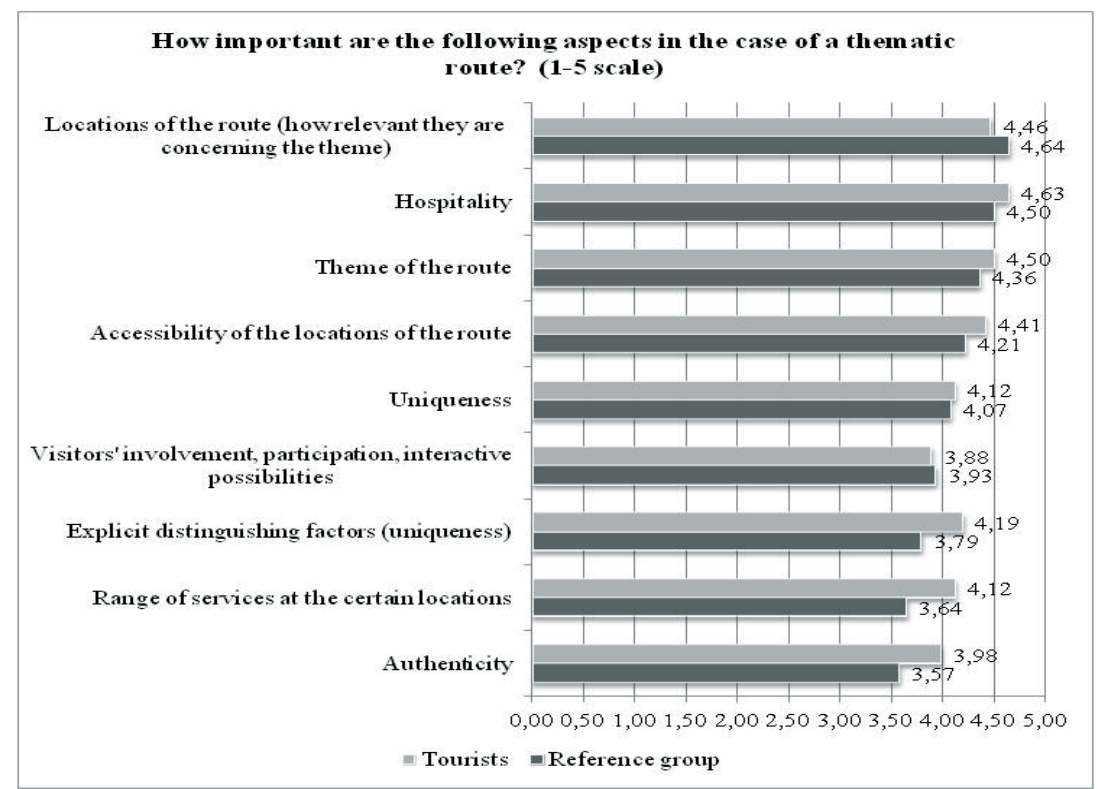

Source: own compilation

Figure 9. Importance of certain aspects in case of thematic roads

An important part of the questionnaire related to the different services of a thematic route. We listed altogether 44 services, which then could form six bigger groups: theme, formation, accessibility, marketing and services.
Regarding marketing tools, we highlighted the aspects of packaging separately.

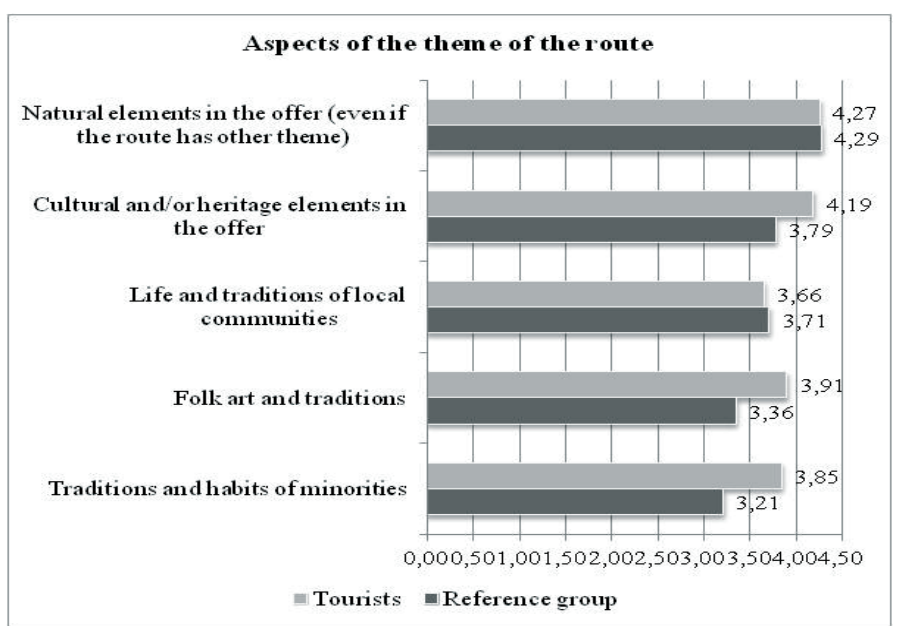

Source: own compilation

Figure 10. Importance of theme-aspects in case of thematic routes 
Regarding the theme (Figure 10), minority and folk art values are less interesting for tourists visiting the area than are natural and cultural values; the high number of gipsy people depresses this micro-region, yet - in spite of every disadvantage - they were able to create a unique "painted village" in Bódvalenke. Visitors considered sustainability and environmentally consciousness as the most important factors when forming a thematic route. Scientific background and historical authenticity are not important for the average tourist, in accordance with the analysis of Figure 9. Regarding accessibility, the suitable signposting of the beginning and end of the route, enough information boards and route signals are the most important aspects, and tourists seem not to bother much about the quality of roads and other traffic services. Brochures, maps, a website of the route and information at the accommodations are the most important marketing tools for tourists, and they are less interested in special discounts or souvenirs. Surprisingly, they do not consider mobile applications as important factors, even these days, when leading tourist destinations are continuously developing more services and apps (e.g. guided tours or special discounts).

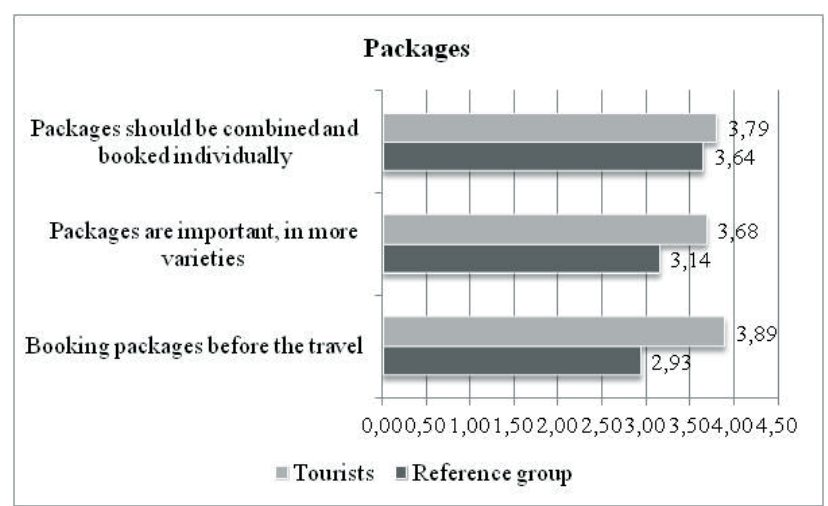

Source: own compilation

\section{Figure 11. Aspects of packaging}

Packaging seems not to be important for the average tourist in Hungary (Figure 11) - an interesting result, as literature defines this tool as an important factor in competitiveness and success, while it does not appear in domestic travel. This reflects the tendency for Hungarian tourists to buy packages mainly in case of international travel - for domestic excursions, it is "out of fashion". The fall in the demand for domestic packages results in another tendency, namely, that Hungarian travel agencies do not offer domestic packages, or the offer is insignificant. Nowadays we can mainly find hotel packages as special offers (e.g. Easter Holidays, wellness weekend).

Services formed the biggest group of aspects. Local gastronomy, local products, a sufficient variety of accommodation and restaurants, and various forms of leisure activities seemed to be the most important. It is interesting that local guiding, special vehicles or luggage transfer (when hiking) were not in demand. An exciting question arose after this result: whether the lack of certain services results in demand for them. Can we miss something that we are not even aware of? It could be the topic of another research study.

We have attempted the examination of the consumer (tourist) satisfaction, too, choosing the classic loyalty index (Piskóti 2008):

$$
C L I=\frac{2 S+R+R B}{4}
$$

where $\mathrm{S}$ stands for satisfaction, $\mathrm{R}$ stands for recommendation to others, while $\mathrm{RB}$ stands for repeated buying (i.e. returning travel). The survey gave the following result:

$$
C L I=\frac{2 * 3.86+3.73+3.71}{4}=3.79
$$

The index means that the satisfaction with the area is a bit higher than the average; the value of the intention to return shows the interest, the hidden potentials of the region. There was only one respondent who surely would not recommend the region to others.

\section{CONCLUSIONS, SUGGESTIONS}

We can conclude, based on the previous analysis, that the Cserehát micro-region is a valuable area, however, it is unable to exploit its potential well. Our research, as well as interviews with local actors and developers strengthened our assumption: an organising power, a management centre functioning as a competence centre (Figure 12) that could successfully operate and maintain the History Valley thematic route is missing from the region. 


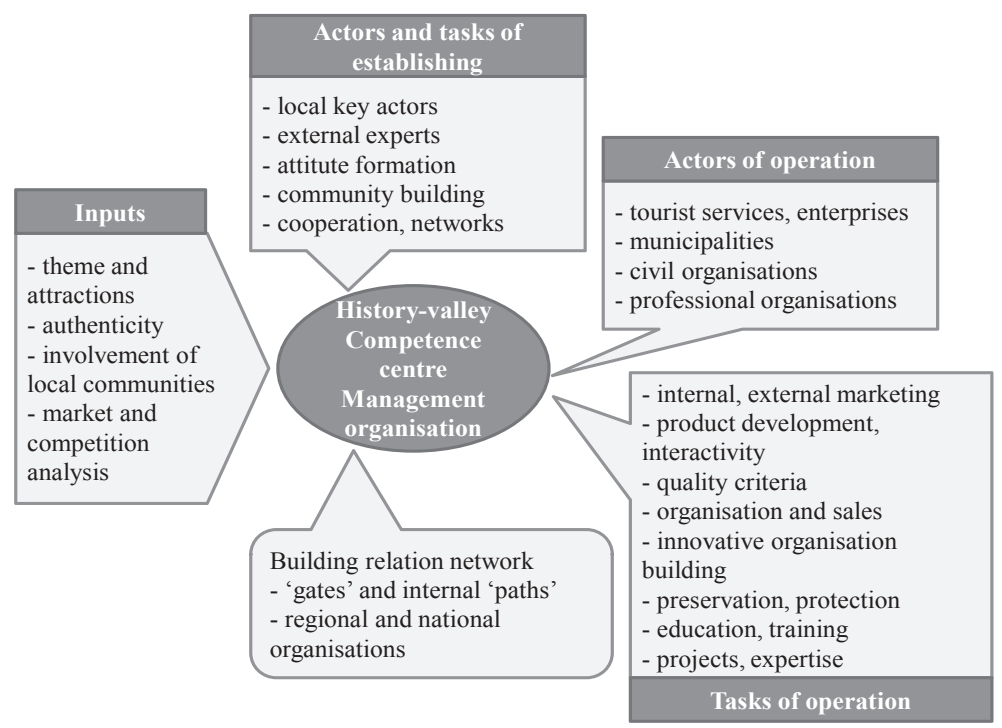

Source: own compilation

Figure 12. Suggested model for the operation of the History Valley route

The first task would be to stimulate life into the route - the conception should be accomplished; this means the tasks of regional community building, networking and innovative organisation. We should put greater emphasis on the gateway functions, which are the entry points to the area: Edelény, Hídvégardó-Tornanádaska and Aggtelek; the last two can be entry points for tourists arriving from the neighbouring Slovakia (Figure 13). Still, the main gateway for the micro-region is Miskolc: the management of the route should build a close relationship with the local destination management agency, as a strategic partner, and develop the cooperation even up to event organisation and sales. As the Cserehát region will not be able to establish its own destination management agency in the near future, they can use the relationship with Miskolc to reach the national network. In addition, they should focus on the establishment of a more innovative organisation with similar functions, based on the local stakeholders' active participation and cooperation. They should carry out active attitude forming work; as we can see from the previous analysis, first, they need to motivate local entrepreneurs and make them visible on tourism's map. They have to devote enough time to building up the organisation and functions, which will take about 3-5 years, and make local actors aware of this.

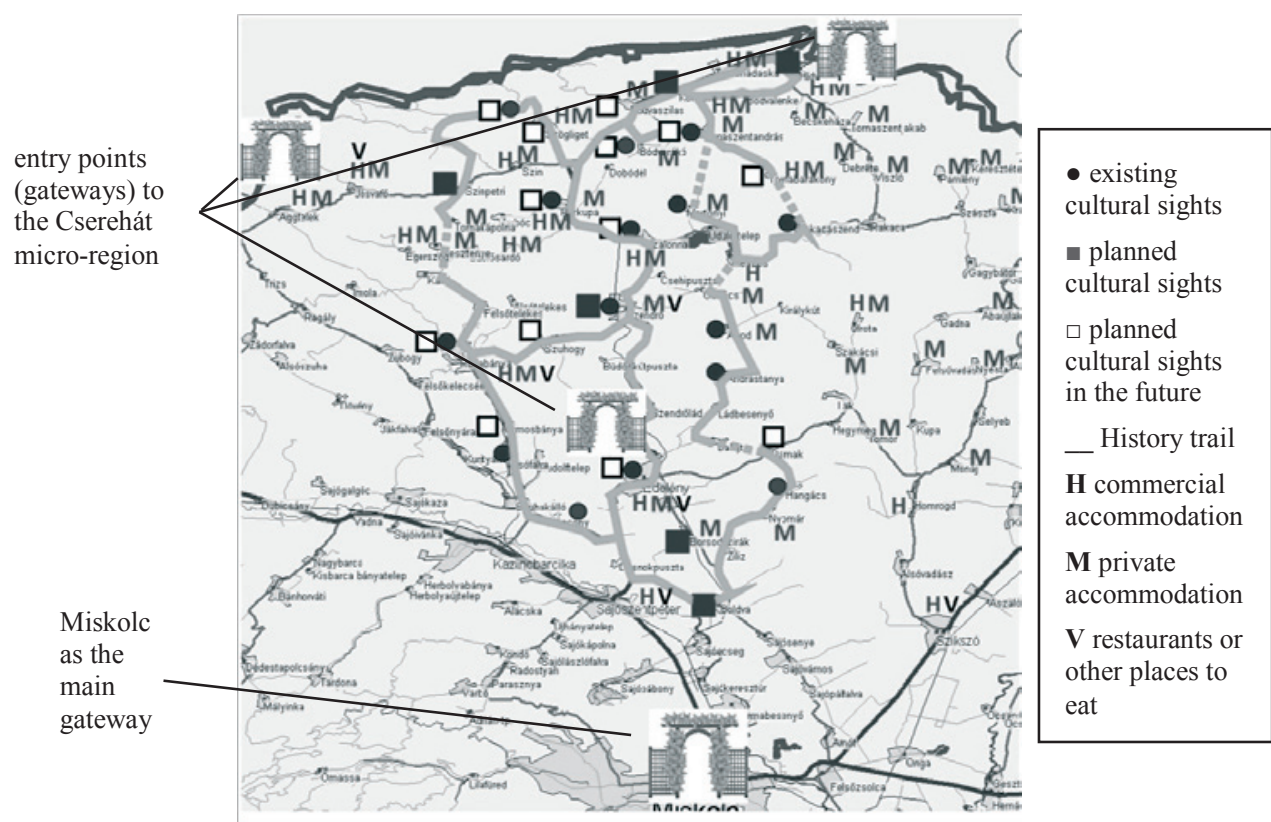

Source: own compilation

Figure 13. Services and gateways of History Valley 
Based on the characteristics of the area's attractions, it is possible to define clear target groups. The attractions should target primarily domestic tourists, mainly from its own and neighbouring regions. It would be essential to reach the population and visitors of the main "gateway", Miskolc - so the area has to begin to build relations with the local destination management agency. Regarding competitiveness, it would also be essential to target tour operators for the sake of organised groups - but it means tasks (e.g. quality assurance and local partners) which seem to be impossible without the local management organisation.

As the first step of the realisation, we suggest to set up a "virtual destination management organisation", which requires at least one person who can take on the challenge of the organising and coordinating work, perhaps as an enterprise. The main tasks are changing the attitudes and networking; then some packages can be built on the involved services. Cooperation with Miskolc can make the area more visible to tourists. Parallel to this, they should update and manage continuously the History Valley website (the respondents marked this as an important element in the previously presented survey); thus, it can be a primary information source and a marketing tool in the beginning, and later a platform for online booking, too.

\section{REFERENCES}

AIKAWA, N. (2007), Patrimonio cultural intangible: nuevos planteamientos respecto a su salvaguardia, Retrieved: September 2016, http://132.248.35.1/cultura/informe/ informe\%20mund2/PATRIMONIO.htm.

BARTHA, Z. \& MOLNÁR, L. (2016): The SLEM model as an assessment method for local goods' competitiveness. Theory, Methodology, Practice, 12(special issue), pp. 5-13. http://dx.doi.org/10.18096/TMP.2016.02.01

BOSWIJK, A., THIJSEN, T., \& PEELEN, E. (2005): A new perspective on the experience economy: Meaningful experiences. The European Centre for the Experience Economy, The Netherlands. Retrieved: September 2013: http://yuiworld.files.wordpress.com/2011/07/1-a-new-perspective -on-the-experience-economy.pdf

BRIEDENHANN, J., WICKENS, E. (2004): Tourism routes as a tool for the economic development of rural areas vibrant hope or impossible dream? Tourism Management, Vol.25. pp.71-79. http://dx.doi.org/10.1016/s02615177(03)00063-3

DEMÉNY, A \& MUSINSZKI, Z. (2016). Social accounting - In the wake of the sustainability. Theory, Methodology, Practice, 12(special issue), pp. 26-40. http://dx.doi.org/10.18096/TMP.2016.02.03

G. FEKETE, É. (2016). A postmodern employment model on the peripheries. Theory, Methodology, Practice, 12(special issue), pp. 41-54. http://dx.doi.org/10.18096/TMP.2016.02.04

GRASSELli, G. (Ed.) (2011): Logisztika jegyzet, Debreceni Egyetem (Retrieved: September 2015, www.agr.unideb.hu/ebook/logisztika/index.html) [Lecture Notes in Logistics, University of Debrecen]

HALL, C.M., MCARTHUR, S. (1998): Integrated Heritage Management. Stationery Office, London

ILLÉS, M. (2016). Enterprise Models from Terms of Sustainability. Theory, Methodology, Practice, 12(special issue), pp. 55-67. http://dx.doi.org/10.18096/TMP.2016.02.05

KINCSES, Á., RÉDEI, M. (2010): Centrum-periféria kérdések a nemzetközi migrációban. [Questions of centreperiphery in the international migration] Tér és Társadalom XXIV. évf. (4. sz.) pp.301-310.

LIGHT, D., PRENTICE, R. (1994): Market-based product development in heritage tourism. Tourism Management Vol.15. (Nr.1.) pp.27-36. http://dx.doi.org/10.1016/0261-5177(94)90024-8

LOURENS, M. (2007a): The Underpinnings for Successful Route Tourism Development in South Africa. Dissertation for Masters Degree of Tourism, University of Witwatersrand, Johannesburg (Retrieved: June 2015: http://wiredspace.wits.ac.za/bitstream/handle/10539/ 4887/Masters\%20Thesis\%20Routes\%20Tourism.pdf?sequence=2)

LÖCSEI, H., SZALKAI, G. (2008): Helyzeti és fejlettségi centrum-periféria relációk a hazai kistérségekben. [Location and development centre-periphery relations in Hungarian small regions] Területi Statisztika XLVIII. évf. (10. sz.) pp.305-314.MAJDOUB, W. (2010): Analyzing cultural routes from a multidimensional perspective. AlmaTourism Nr.2. pp.29-37.

MARTORELL-C, A. (2003): Cultural Routes: Tangible and Intangible Dimensions of Cultural Heritage. ICOMOS [www.icomos.org] (Retrieved: February 2013: http://www.international.icomos.org/victoriafalls2003/papers/A15\%20-\%20Martorell.pdf) 14th ICOMOS General Assembly and International Symposium: 'Place, memory, meaning: preserving intangible values in monuments and sites', 27 - 31 Oct- 2003, Victoria Falls, Zimbabwe

MEYER, D. (2004): Tourism Routes and Gateways: Key issues for the development of tourism routes and gateways and their potential for pro-poor tourism. Overseas Development Institute (Retrieved: March 2013: http://www.odi.org/sites/odi.org.uk/files/odi-assets/publications-opinionfiles/4040. pdf) 
NURYANTI, W. (1996): Heritage and Postmodern Tourism. Annals of Tourism Research. Vol.23. Iss.2. pp. 249-260.

PEDERSEN, A. (2004), The Possible Tangible Benefits of Working on Intangible Heritage Issues at World Heritage Sites, Forum Barcelona 2000, Barcelona.

PISKÓTI, I. (2008): Elégedettség- és értékorientált ügyfélmenedzsment-modell keretei. [The frames of satisfaction and value oriented customer relation management model] In: Piskóti, I. (szerk.): Marketingkaleidoszkóp 2008. Miskolci Egyetem, pp.11-36.

PISKÓTI, I. (2014): Innovációvezérelt desztinációmarketing - trendek és teendők. [Innovation-driven destination marketing] Észak-magyarországi Stratégiai Füzetek, Vol.11. Iss.2. pp.32-44.

POON, A. (1989) Competitive strategies for a new tourism', in C. Cooper, ed, Progress in Tourism, Recreation and Hospitality Management, Volume 7, Belhaven, London, pp 91-102.

PUCZKÓ L., RÁCZ T. (2000): Az attrakciótól az élményig [From an attraction to an experience], Geomédia Kiadó, Akadémiai Kiadó Budapest

PUCZKO, L., RATZ, T. (2003), The Role of NGO in Heritage Information and Management in Gravari-Barbas, M. and Guichard-Anguis, S., Regards Croisés sur le Patrimoine dans le Monde à l'Aube du XXIème siècle, Paris: Presses de l'Université de Paris Sorbonne.

ROGERSON, C.M. (2004): Tourism and uneven local economic development: the experience of route tourism in South Africa. In: C.M.Rogerson \& G.Wisser (eds): Tourism and Development Issues in Contemporary South Africa, Pretoria, Africa Institute of South Africa, pp.399-419.

ROGERSON, C.M. (2007): Tourism routes as vehicles for local economic development in South Africa. The example of the Magaliesberg Meander, Urban Forum, Vol.18.

ROGERSON, C.M., ROGERSON, J.M. (2011): Craft routes for developing craft business in South Africa: Is it a good practice or limited policy option? African Journal of Business Management, Vol.5. (Nr.30.) pp.11736-11748.

SCHLÜTER, R.G. (2012): Promoting regional cuisine as intangible cultural heritage in Latin America. In: OECD (2012): Food and the Tourism Experience.

SWARBROOKE, J. (1994): The Future of the Past: Heritage Tourism in the 21st Century. In: Seaton, A.V. (ed.): Tourism: The State of the Art. John Wiley and Sons, Chichester, England

TELFER, D.J. (2001): Strategic alliances along the Niagara Wine Route. Tourism Management, Vol.22. pp.21-30.

VÁRKONYI, M. J. (2016). Challenges of establishing and operating social enterprises. Theory, Methodology, Practice, 12(special issue), pp. 68-74. http://dx.doi.org/10.18096/TMP.2016.02.06 